\title{
CONCENTRATIONS OF NITROGEN DIOXIDE, CARBON AND OZONE MONOXIDE IN TIG WELDING OF ALLOYS 1460 AND 1201
}

\section{Lukianenko Anna ${ }^{1}$ \\ Goncharova Olga ${ }^{2}$}

DOI: https://doi.org/10.30525/978-9934-571-89-3_115

Aluminum alloys are used in welded structures of different purpose. They are characterized by a favourable combination of physical and chemical properties, which makes them attractive for application in the aerospace and rocket engineering industry. In addition to the advantages, when performing welding process, aluminum alloys are characterized by the formation of harmful and hazardous production factors [1, p. 1].

${ }_{2}^{1}$ E.O. Paton Electric Welding Institute of the NAS of Ukraine, Ukraine
${ }^{2}$ E.O. Paton Electric Welding Institute of the NAS of Ukraine, Ukraine 
During welding of the system 1460 (Al-Cu-Li) and the system 1201 (Al-Cu) with non-consumable tungsten electrode, along with the formation of welding aerosols (solid component of welding aerosol, SCWA), harmful welding gases (gaseous component of welding aerosol, GCWA) are evolved to the air of the working zone, belonging to the group of chemical hazardous and harmful production factors $[2$, p. 1 ; 3 , pp. 33, 34]. The most widespread in the composition of mixture of welding gases is nitrogen dioxide $\mathrm{NO}_{2}$, carbon monoxide $\mathrm{CO}$ and ozone $\mathrm{O}_{3}$.

The aim of the work is to conduct investigations of harmful gases in argon-arc welding of alloys of the system $1460(\mathrm{Al}-\mathrm{Cu}-\mathrm{Li})$ and the system $1201(\mathrm{Al}-\mathrm{Cu})$ with non-consumable tungsten electrode.

The investigations of the sanitary and hygienic characteristics of harmful gases at the workplace were carried out during TIG welding of high-strength, complexalloyed aluminum alloys 1460 and 1201 with a thickness of $3.0 \mathrm{~mm}$. TIG welding was carried out using the welding head ASTV - 2M from the power source MW - 450 of the Austrian company Fronius with the use of non-consumable electrode and the power source IUP-1 made in the USSR. Sampling and investigation of the mentioned gases were carried out in the range of welding modes $I_{w}=140 \ldots 260$ A.

Sampling was carried out keeping in compliance with DSTU ISO 15011-2:2008 [4, p. 4], and in accordance with the guidelines [5, p. 37], harmful gases were determined. To provide reliability of the obtained results of the investigations, at least 6 samples were taken. The concentration of constituents in a gaseous component of welding aerosols of nitrogen dioxide $\mathrm{NO}_{2}$ and carbon monoxide was determined using the devices "Aquilon 1-1" and "Aquilon 1-2". The concentration of the component in a GCWA of ozone was determined using the colometric method by sampling, applying the sampler "Typhoon" and the absorbing device with a potassium iodide solution. The condition of the air environment of the workroom was assessed in accordance with the requirements of GOST 12.1.005-88 [6, p. 1].

It was established that welding current strength significantly influences the formation of nitrogen dioxide, increasing its concentration to the values, exceeding its maximum permissible concentration (MPC) $=2.0 \mathrm{mg} / \mathrm{m}^{3}$. The concentration of carbon monoxide is almost unchanged. In the range of welding currents of $140 \ldots 260 \mathrm{~A}$, the mass concentration of $\mathrm{CO}$ is approximately equal to $1 \mathrm{mg} / \mathrm{m}^{3}$ and is much lower than its MPC $=20 \mathrm{mg} / \mathrm{m}^{3}$. The results of measurements are given in Tabl. 1 taking into account the error.

Table 1

Concentration of $\mathrm{CO}$ and $\mathrm{NO}_{2}$ in the workplace during welding of aluminum-lithium alloy 1460 depending on welding mode

\begin{tabular}{|c|c|c|}
\hline \multirow{2}{*}{ Welding current strength I, $\mathbf{A}$} & \multicolumn{2}{|c|}{ Mass concentration $\mathbf{C , ~} \mathbf{~ m g / \mathbf { m } ^ { \mathbf { 3 } }}$} \\
\cline { 2 - 3 } & $\mathbf{C O}$ & $\mathbf{N O}_{\mathbf{2}}$ \\
\hline 140 & $0.4 \pm 0.7$ & $1.1 \pm 0.5$ \\
\hline 200 & $0.5 \pm 0.8$ & $1.3 \pm 0.5$ \\
\hline 260 & $0.5 \pm 0.8$ & $2.5 \pm 0.6$ \\
\hline
\end{tabular}


Figure 1 shows that the dependence of the nitrogen dioxide concentration is approximated by the parabola at a high precision, and therefore, the volume of the formed toxic gas grows significantly with an increase in the welding current as $\mathrm{C} \sim \mathrm{I}^{2}$.

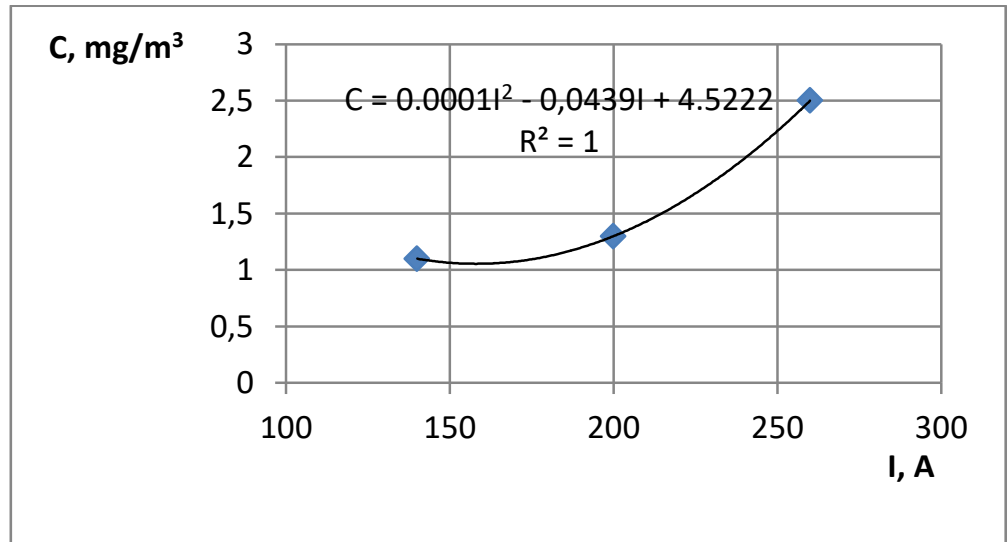

Figure 1. Dependence of mass concentration of nitrogen dioxide at the workplace during argon-arc welding of aluminum-lithium alloy 1460

The concentration of ozone during welding also increases with the rise in welding current strength. At the same time, the concentration of $\mathrm{O}_{3}$ exceeds its MPC $=0.1 \mathrm{mg} / \mathrm{m}^{3}$ at all modes of welding: at $I_{w}=140$ A the concentration is $0.13 \mathrm{mg} / \mathrm{m}^{3}$, and at $I_{w}=260$ it is $A-0.49 \mathrm{mg} / \mathrm{m}^{3}$. For the alloy 1460 , the ozone concentration exceeds the MPC (Figure 2).

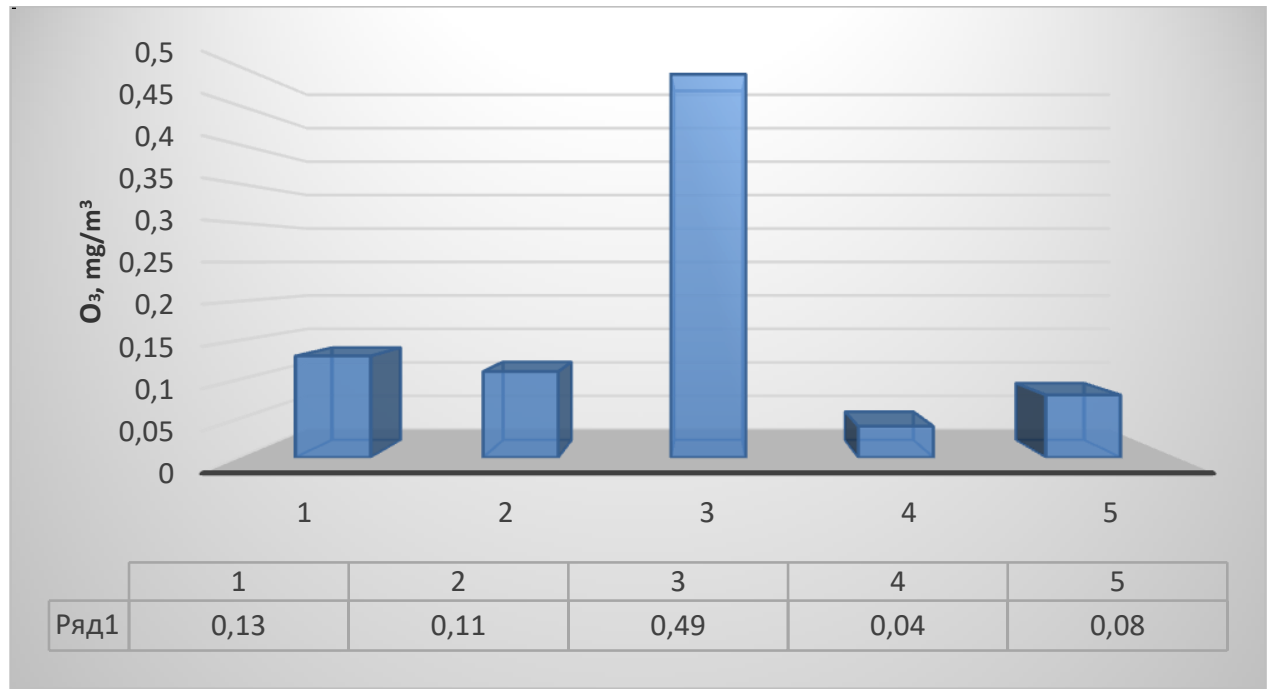

Figure 2. Dependence of ozone concentration on welding mode during welding of alloys $1460\left(1-I_{w}=140 \mathrm{~A}, 2-I_{w}=200 \mathrm{~A}, 3-I_{w}=260 \mathrm{~A}\right)$ and $1201\left(4-I_{w}=140 \mathrm{~A}, 5-I_{w}=260 \mathrm{~A}\right)$ with non-consumable electrode

Thus, it was established that TIG welding of alloys of the system 1460 (Al-Cu-Li) and the system 1201 (Al-Cu) is accompanied by the formation of toxic gases at the workplace: nitrogen dioxide, carbon monoxide and ozone; that in the range of welding currents of $140 \ldots 260 \mathrm{~A}$, the mass concentration of carbon oxide $\approx 1 \mathrm{mg} / \mathrm{m}^{3}$ is much lower than its MPC; that the mass concentration of nitrogen dioxide exceeds 
its MPC at intense welding conditions and significantly depends on welding current; that the concentration of ozone during welding of the alloys 1460 and 1201 with nonconsumable electrode increases with the risen welding conditions. At the same time, for the alloy 1460 the ozone concentrations exceed MPC and the level of ozone concentration is 3-4 times higher than that during welding of 1201 at identical modes.

\section{References:}

1. Luk'yanenko A.O., Labur T.M., Poklyatskiy A.G., Kuleshov V.A., Darko R. (2017) Sanitarno-gigienicheskaya kharakteristika protsessa argonodugovoy svarki neplavyashchimsya elektrodom alyuminievykh splavov 1201 i 1460 (Sanitary-hygienic characteristics of the process of argon-arc welding by non-consumable electrode of aluminum alloys 1201 and 1460) Avtomat svarka, no 10, pp. 57-61.

2. GOST 12.0.003-74. SSBT. Opasnye i vrednye proizvodstvennye faktory. Klassifikatsiya (Dangerous and harmful production factors. Classification).

3. Levchenko O.G. (2015) Svarochnye aerozoli i gazy: protsessy obrazovaniya, metody neytralizatsii i sredstva zashchity (Welding aerosols and gases: formation processes, neutralization methods and means of protection). Kiev, nauk. Dumka. (in Ukrainian)

4. DSTU ISO 15011-2:2008. Okhorona zdorov'ya ta bezpeka u zvaryuvanni ta sporidnenikh protsesakh. Laboratorniy metod vidbirannya aerozoliv i gaziv, utvoryuvanikh pid chas dugovogo zvaryuvannya. Chastina 2. Viznachennya rivnya vidilen' gaziv, za vinyatkom ozonu (Okhorona zdorovya'ya that bezpeka at the beginning of that process. Laboratory method of aerobolic aerosols and gas, which were completed in an arc arcane mode. Chastina 2. Viznachennya vivnya vidilen gaziv, for vinyatkom ozone) Kiev, Derzhspozhivstandart Ukraïni, p. 10. (in Ukrainian)

5. Metodicheskie ukazaniya po opredelenie vrednykh veshchestv v svarochnom aerozole (tverdaya faza i gazy): Metodicheskie ukazaniya № 4945-88 (1990) (Guidelines for the determination of harmful substances in the welding aerosol (solid phase and gases): Guidelines) Moscow, Minzdrav SSSR, p. 150. (in Russian)

6. GOST 12.1.005-88. SSBT. Obshchie sanitarno-gigienicheskie trebovaniya $\mathrm{k}$ vozdukhu rabochey zony. Vved. 01.01.1989 (1988) (GOST 12.1.005-88. SSBT. General sanitary and hygienic requirements for working area air),. Moscow, Gosstandart SSSR, p. 75. (in Russian) 